\title{
Dialectics of Forgiveness between Ethnic Communities for West Kalimantan Harmony
}

\section{Dialektika Pengampunan antar Komunitas Etnis untuk Keharmonisan Kalimantan Barat}

\author{
Rustono Farady Marta ${ }^{1}$, Joshua Fernando² \\ ${ }^{1}$ Magister of Communication Science, Universitas Bunda Mulia, Jl. Lodan Raya No. 2, \\ Jakarta 14430, Indonesia \\ ${ }^{2}$ Study Program of Communication Science, Faculty of Communication Sciences, \\ Universitas Mpu Tantular, Jl. Cipinang Besar No. 2, Jakarta 13410, Indonesia \\ *Corresponding author, e-mail: rmarta@bundamulia.ac.id
}

\begin{abstract}
West Kalimantan has a history of inter-ethnic conflicts, and the process of reconciliation has been continued until today in order to create a complete peace. This present study uses the qualitative method of explorative case study from the perspective of Arendt's Political Forgiveness Theory to analyze the process of individual forgiveness in the ongoing reconciliation process. The results indicate that the dialectics of forgiveness practices that occur individually cannot be achieved completely due to several factors, but the presence of the West Kalimantan Children's Forum, the Madurese Family Association, the Alliance for Peace and Transformation, and the Dayakology Institute stimulates the emergence of collective forgiveness for the past interethnic conflicts in the younger generation in West Kalimantan. The findings suggest that sustainable justice is the main solution that will enable all ethnic groups to live in harmony.

Keywords: Dialectics of Forgiveness, Arendt's Political Forgiveness Theory, Ethnic Communities, Young Generation.

Abstrak

Kalimantan Barat memiliki sejarah konflik antar-etnis, dan proses rekonsiliasi telah berlanjut hingga hari ini untuk menciptakan perdamaian yang seutuhnya. Penelitian ini menggunakan metode kualitatif studi kasus eksploratif dari perspektif Teori Pengampunan Politik Arendt untuk menganalisis proses pengampunan individu dalam proses rekonsiliasi yang masih berlangsung. Hasilnya menunjukkan bahwa dialektika praktik pengampunan yang terjadi secara individual tidak dapat dicapai sepenuhnya karena beberapa faktor, tetapi kehadiran Forum Anak-Anak Kalimantan Barat, Asosiasi Keluarga Madura, Aliansi untuk Perdamaian dan Transformasi, serta Institut Dayakologi merangsang munculnya pengampunan kolektif untuk konflik antar-etnis masa lalu pada generasi muda di Kalimantan Barat. Temuan menunjukkan bahwa keadilan berkelanjutan adalah solusi utama yang akan memungkinkan semua kelompok etnis untuk hidup dalam harmoni.
\end{abstract}

Kata Kunci: Dialektika Pengampunan, Teori Pengampunan Politik Arendt, Kelompok Etnis, Generasi Muda.

\section{Introduction}

The history of inter-ethnic conflicts in West Kalimantan which happened about two decades ago has entered a stage of reconciliation which has become a priority agenda by various groups in the society. From the cultural aspect, various groups, organizations, and institutions currently have shared the same vision for the establishment of peace in West Kalimantan.

Article History: Received June 01, 2019; Revised January 19, 2020; Accepted January 26, 2020; Published January 31, 2020 


\begin{tabular}{ccc}
\hline Ethnic Group & Total & Concentration \\
\hline Malay & 1.259 .890 & $33.75 \%$ \\
Dayak & 1.259 .802 & $33.75 \%$ \\
Tionghoa & 373.690 & $10.01 \%$ \\
\hline
\end{tabular}

Table 1. West Kalimantan Ethnicity (BPS, 2003)

At present, the population of West Kalimantan consists of various ethnic groups. In general, the three largest ethnic groups are Malay, Dayak, and Chinese. The Chinese ethnic group is more commonly referred to as 'Tionghoa' in Pontianak as shown in Johannes and Rasyid (2017). The multiethnic groups have coexisted peacefully in West Kalimantan although the potential for conflicts still exists. This is in line with Wirawan's idea of intercultural conflicts (Paramita \& Carissa, 2018). Wirawan (2009) is of the opinion that any instances of intercultural communication that do not run smoothly in their processes of sending, receiving and decoding messages may have the risk of creating misunderstandings between individuals or groups of people which eventually can lead to intercultural communication conflicts. Therefore, the potential for conflicts has become the biggest challenge for heterogeneous communities in a region.

The history of Indonesia has been marked with major inter-ethnic conflicts which had erupted since 1999, and they came as a shock for many people from the local, national and international levels. The Ambon case, for instance, was started as a minor incident involving members of certain ethnic groups, but then it escalated into interreligious conflict between Muslims and Christians in the area (Safi, 2017).

Several examples of inter-ethnic conflicts can be found in West Kalimantan. Arkanudin (2006) points out that inter-ethnic conflicts between Dayak people and Madurese had occurred repetitively. Table 2 shows the time span and frequencies of these conflicts between the two ethnic groups.

\begin{tabular}{ccc}
\hline Time Span & Number of Conflicts & Source \\
\hline $1933-1997$ & 10 times & Arafat, 1998 \\
$1962-1999$ & 11 times & Alqadrie, 1999 \\
$1952-1999$ & 12 times & Petebang \& Sutrisno, 2000 \\
\hline
\end{tabular}

Table 2. Dayak and Madurese Conflicts in West Kalimantan

The biggest inter-ethnic conflict between Dayak and Madurese people broke out in 1997, and most of the skirmishes occurred in West Kalimantan. Following this conflict, there was also a conflict between Malay and Madurese because of an allegation that one Malay was killed by a Madurese in 1999. At that time, around 48,000 people had to flee from the conflict areas and sought refuge in Pontianak City and Pontianak Regency (Subro, 2011).

Hidayat (2013) explains that the conflict in West Kalimantan may be triggered by the creation of the so-called 'dominant culture' by Dayak and Malay people which put Madurese people as the minority in the region. With a long and traumatic history of conflicts, the stereotyping of each ethnic group has been created, and, as time passes by, the communication practices between the ethnic groups indicate that many young people have received this stereotyping from the exposures of media which show cruelties happening during the inter-ethnic conflicts and the examples of injustice experienced by certain marginalized ethnic groups living in the multi-ethnic society in West Kalimantan (Fernando \& Marta, 2015).

Acknowledging the idea of multiculturalism can be considered as one of the means to accommodate equality and diversity as a concept that can resolve vertical and horizontal conflicts in a heterogeneous society, in which demands for recognition of

Jurnal The Messenger, Vol. 12, No. 1, January 2020, pp. 1-13 
existence and cultural uniqueness of each ethnic group are commonly shared. A multicultural society is created to provide enough space for various ethnic groups to carry out their lives autonomously, and, by doing so, it is expected that a well-established cultural system and social order are constructed in the society which eventually can serve as one of the pillars to maintain peace in our nation (Marta, 2018).

In the hope of reaching a reconciliation stage, a seed of harmony arose among the younger generation of the West Kalimantan ethnic groups that had involved in the conflicts in the past. The seed was planted by the West Kalimantan Children's Forum, an organization consisting of children under the age of 18 , which serves as a forum in which children from various ethnic groups can gather for the purpose of voicing their unanimous opinions and appeals for the complete fulfillment of their rights as children who live in a multicultural society with the potential of future inter-ethnic conflicts.

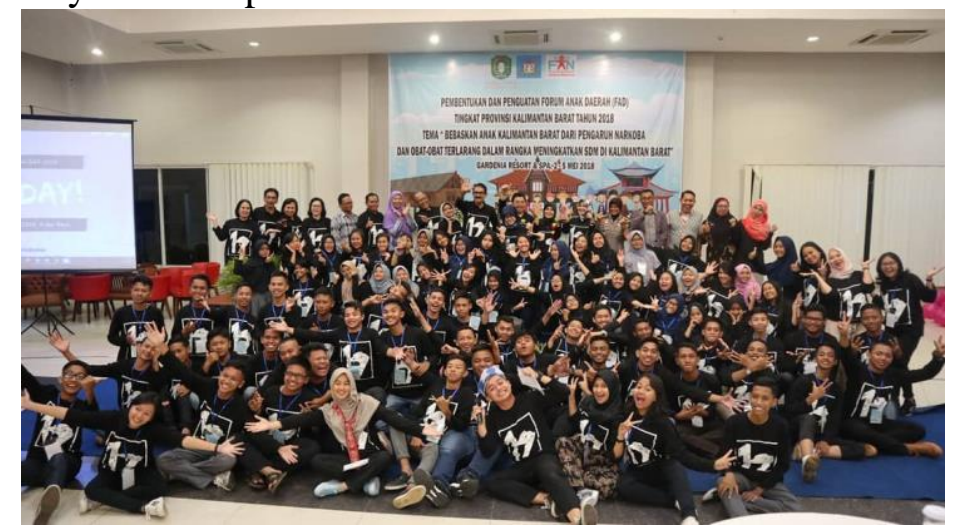

Figure 1. West Kalimantan Children's Forum 2018 (source: the researchers)

From the communication perspective, the West Kalimantan Chidren's forum is like an organization, and the basic determinant of the organization's success or failure is the communication practices among the members of the organization (Sahertian \& Elbaar, 2016). This means that the communication made by each member of the West Kalimantan Children's Forum also has an important role in the creation of harmonious relationships among the ethnic groups. In addition, it is common for an organization to experience an improved performance of the members which can help them achieve the organization's objectives if the relationship among the members runs smoothly and harmoniously because of mutual respect and mutual openness among them (Sahertian \& Elbaar, 2016).

The dictinctive characteristic of intercultural communication is the involvement of people from different backgrounds, such as ethnic groups, languages, foods, clothing, manners, customs, and social behavior in the communication (Yohana \& Yozani, 2017). In some regions in Indonesia, the harmony in intercultural communication is demonstrated by inter-ethnic marriages (Fernando, Sya, \& Marta, 2019).

The various cultural backgrounds of the communication participants might result in the differences in their patterns of conveying and interpreting the messages. This is why a good communicator would accommodate the interlocutors' style of speaking, cultural and academic backgrounds, and objectives in order to reach mutual understanding (Yohana \& Yozani, 2017). This can also be applied in the West Kalimantan Children's Forum. The role of an individual (a communicator) in the forum becomes important when s/he acts as an agent who can accommodate his/her relationship with others in the Forum to create harmony between ethnic groups in the Forum.

To support this present study, the following previous studies are considered as the state-of-the-art references related to the topic. 


\begin{tabular}{cc}
\hline Title & Author \\
\hline 'Jati Diri Manusia berdasarkan Filsafat Tindakan Hannah Arendt dari & \\
Perspektif Filsafat Manusia: Relevansi dengan Pelanggaran HAM tahun & Indah (2016) \\
1965-1966 di Indonesia' (Human Identity based on Hannah Arendt's & \\
Philosophy of action from the Perspective of Human Philosophy: Its & \\
Relevance with the 1965-1966 Human Rights Violations in Indonesia) & \\
'The Personal and the Political: Forgiveness and Reconciliation in & Kohen (2009) \\
Restorative Justice' & Sumarni, Bahari, \\
'Interaksi Sosial kerja sama Masyarakat Multietnis (Dayak, Madura, & $\begin{array}{c}\text { \& Sulistyarini } \\
\text { Melayu) di Desa Kenaman, Kecamatan Sekayam' (Social Interactions } \\
\text { within cooperations among a Multiethnic Society (Dayak, Madurese, and } \\
\text { Malay) in Kenaman Village, Sekayam Subdistrict) }\end{array}$ \\
'Hubungan Sosial antara Etnis Banjar dan Etnis Madura di Kota & Hidayat (2013) \\
Banjarmasin' (Social Relationships between Banjar Ethnic Group and & \\
Madurese Ethnic Group in Banjarmasin City) & \\
\hline Table 3. Previous Studies on the Topic (source: the researchers)
\end{tabular}

The previous studies in table 3 are of two categories. First, the previous studies which can help the researchers of this present study develop their analyses based on Arendt's theory of the politics of forgiveness in the process of reconciliation and justice. Second, there are previous studies which focus on the inter-ethnic cooperation which has existed in two different regions in Indonesia and which has resulted in harmony. Subsequently, the present study is placed in the niche of the two categories by focusing on the case of inter-ethnic community reconciliation in West Kalimantan, which has been reflected in the West Kalimantan Children's Forum.

In her theory of forgiveness, Arendt offers conditions regarding forgiveness in which one can turn over a new leaf in one's life by giving forgiveness to others (as cited in Indah, 2016). Forgiveness can also overcome past grudges because by forgiving others, the victims and the guilty parties have new opportunities to be introspective and start a new life. In addition, giving forgiveness enables us to cancel past actions (Arendt, 1958).

Indah (2016) defines reconciliation as the disclosure of truth and justice, which usually involves the government acts of granting pardon and compensation for the guilty parties. Forgiveness or pardon can help restore the conditions to zero or reconciliation. In the West Kalimantan Children's Forum, children who may be the descendants of rival parties during the inter-ethnic conflicts are taught not to look back at the conflicts in the past in order to create harmony; however, outside the Forum, there are many forms of recalling the conflicts, i.e. stories of past inter-ethnic conflicts, media exposure about the conflicts, and the emergence of inherent ethnic group stereotyping, which can be consumed by the children. Therefore, the observation of communication process based on the perspective of the theory of political forgiveness is important as it can contribute to the success of the post-conflict-reconciliation process in the West Kalimantan society as represented by the communication practices among the children in the West Kalimantan Children's Forum.

\section{Method}

The present study makes use of qualitative approach from the perspective of subjective interpretive within the symbolic interactionist theory which considers realities to be dual, complex, abstract, and dynamic (Mulyana, 2013). Creswell (1998) is of the opinion that qualitative research is a research process and understanding based on a methodology that can be used to investigate social phenomena and human problems. In 
this present study, the West Kalimantan Children's Forum is a forum in which collective forgiveness is encouraged to emerge among the children who are taught about living in diversity and harmony in West Kalimantan; thus, the reality processes that take place in the Forum are observed and analyzed as to understand the extent of the collective forgiveness emergence.

This present study also uses the exploratory case study method. Yin (2002) explains that a case study can be used to explore situations where the intervention which would be evaluated does not have a single and clear outcome structure. The primary data are collected from the unstructured interviews and document analyses, and the secondary data are gathered from observations and literature reviews (Januarti \& Wempi, 2019). The explanatory case study leads to the use of 'how' and 'why' questions. Therefore, this study seeks data by conducting in-depth interviews of the subjects from young multiethnic children, community leaders, and academics in Pontianak City and Kuburaya District, West Kalimantan.

The children subjects of this present study are several members of the West Kalimantan Children's Forum who come from three major ethnic groups. They are Maulana (Madurese), Farhana Fitria (Malay and Madurese), Hilaria Nugil (Dayak), and Leo Waldi (Dayak). The subjects from community organizations are Subro (Madurese Big Family Association) and Krissusandi Gunui (Institute of Dayakologi). In addition, Professor Yohanes Bahari, M.Si. from the Faculty of Teacher Training and Education, University of Tanjungpura, West Kalimantan, represents the academics.

\section{Results and Discussion}

Looking at the two-decade journey of reconciliation of the West Kalimantan multiethnic community, it is important that the various stakeholders supervise the process. This present study tries to look at forgiveness from the perspective of the younger generation as the descendants of rival parties during the inter-ethnic conflicts. Forgiveness is the ability to redeem something from irreversibility difficulties, i.e. from the inability to undo things that have been done (Arendt, 1958). Arendt goes further by asserting that forgiveness serves to undo past actions and releases the victims and the guilty parties from the consequences of holding grudges and regretting things that could never be recovered (1958); thenceforth, they can start living a better life harmoniously. Pettigrove (2006) mentions two types of Arendt's forgiveness process: individual forgiveness and collective forgiveness.

Self-Forgiveness Construction in the West Kalimantan Children's Forum

This present study selected four children who come from Dayak, Madurese, and Malay ethnic groups by using some criteria, such as children under the age of 18 , members of the children's forum, and living in a heterogeneous environment. Maulana, one of the subjects, is a student from State High School 6 in Pontianak. He is a Madurese. With regard to Arendt's 'ultimate' or the human ability to live together in diversity (as cited in Indah, 2016), Maulana also has his ultimate as he is growing up in a multi-ethnic environment which incudes his school and the East Pontianak Subdistrict Children's Forum.

Maulana's forgiveness construction process was tested when his brother showed him a video about Dayak ethnic group using violence against Madurese around two decades ago in Sampit, Central Kalimantan. The video was showed to Maulana when he was still in his early teens. Maulana's opinion about the violence is presented below. 
"Yes, once I watched the video in which Madurese people were slaughtered ... what would you do, if, for example, it happens to your own family. You will surely feel the anger because your own family become victims. So you will have grudge against the perpetrators, and want to retaliate." (Maulana, personal communication, February 24, 2019, 14.30 WIB--Western Indonesian Time)

This incident hinders the process of reconciliation and forgiveness because the video serves as a recalling medium which reminds Maulana of inter-ethnic conflicts in the past. Nevertheless, Maulana states that he has forgiven the past events because they are already in the past. Maulana consciously displays Arendt's notion that forgiveness is useful to cancel past actions. On the other hand, it looks like Maulana and his family as representatives for Madurese ethnic group are still being cautious with regard to the perpetual potential for conflicts.

A different perspective comes from a member of a Dayak family, Hilaria Nugil, who is a female student of Ambawang Senior High School 2 and a former president of the Ambawang Children Forum, Kubu Raya Regency. Her father comes from a Dayak tribe in Ambawang area, Kubu Raya Regency, and her mother is a Dayak from Pahauman area, Landak Regency. Nugil was the President of the Ambawang Children Forum when she was in Junior High School. Like Maulana, Nuril's forgiveness construction process also happened during her early teens when her mother told her stories about the interethnic conflict between Dayak and Madurese that occurred in Pahauman village, Landak Regency.

"It happened a long time ago. I forgot how old I was, but at that time my grandfather was ill. My mom told me stories of the war between Madurese and Dayak. It seems that there was violence against children during the war. They were tossed to the air, and "tuss"- some blades were waiting for them below. They were Madurese children. It happened somewhere in Pahauman area where my mother used to live. Now, there are not any Madurese people in that area." (Nugil, personal communication, March 1, 2019, 19.32 WIB--Western Indonesian Time)

Through the stories from Nugil's mother, the recalling process occurred, and the younger generation was introduced to conditions of inter-ethnic conflicts in the past. Arendt (1958)describes three basic human activities, one of which is action. This action of telling stories like Nugil's mother creates memories of the incidents during the past conflicts, and the younger generation, like Nuril, have recorded the stories and have stored them in their memories until today. Furthermore, Nugil's understanding of the conflict put her in the place as if she and her Dayak people were the guilty party for the conflict because the stories told that Dayak people had killed people from another ethnic group.

Arendt (1958) describes two conditions for forgiveness. The first one is forgiveness because the offensive action was commited unconsciously, and the second one is forgiveness because of humanity consideration. In the story of Nugil, she further explained about the violent mistakes made through unintentional words or unconsciously and those which are made under mystical influences which makes the affected humans become unaware of their actions.

"If, for example, Nugil thought first, if I am not mistaken it was the Madurese people who started the rampage, and they made the Dayak generals upset. And I am thinking of giving them forgiveness, because the conflict was triggered by unintentional words. If we can understand the reasons of this, I am sure they would be forgiven." (Nugil, personal communication, March 1, 2019, 19.32 WIB--Western Indonesian Time) 
Nugil as a young generation of Dayak has forgiven the rival parties in the conflict on the basis of humanity, and she feels that each ethnic group must conduct selfintrospection to guarantee future harmony. Individual forgiveness as experienced by Maulana and Nugil has not been fully realized because there are still various aspects that need to be taken into considerations, such as listening to past stories, the stereotyping, and exposure to media contents about the inter-ethnic conflict situations in the past. This forgiveness process requires help from collective stakeholder groups in order to reach complete forgiveness.

Collective Forgiveness Construction in the West Kalimantan Children's Forum

The awareness to forgive others does not happen in an instant. It needs a construction process which would make the forgiveness event becomes a very important process, and it takes years to see the results of this forgiveness process so that the roles of various stakeholders are very important to create harmony between the groups. Man, Abdullah, Tamam, \& Hasan (2019) explain that the organization's goal depends on the contents of its communication strategy which is influenced by the process by which it is formed and by individuals and layers of organizations who have interests in it. Likewise, the objective of West Kalimantan Children's Forum is to become a forum for young people coming from several multi-ethnic groups who gather, discuss, and learn together about the characters of each member to create harmony.

In general, the West Kalimantan Children's Forum is divided into several branches based on the number of cities and districts in West Kalimantan. The fourteen districts and cities in West Kalimantan are encouraged to form a Children's Forum down to the subdistrict or village level according to the appeal from the Ministry of Women's Empowerment and Child Protection. This national program is called the Child Friendly City which means every regency or city must have its development identity based on the Child Rights through the integration of commitments from government resources, communities, and business which are comprehensively and sustainably planned in policies, programs, and activities to guarantee the fulfilment of the children's rights and protection. Various activities are carried out for the children joining the Children's Forum, and they are done based on non-discrimination, togetherness, and diversity because the members come from various ethnic groups and backgrounds.

"... at the Ambawang Children's Forum I can talk confidently without hesitation. I learned many things about leadership in the Ambawang Children's Forum. I learned how to be a leader, to know how to run an organization, how to interact with others, and how to be a creative child. It's really remarkable to participate in the Ambawang Children's Forum." (Waldi, personal communication, March 1, 2019, 16.58 WIB--Western Indonesian Time)

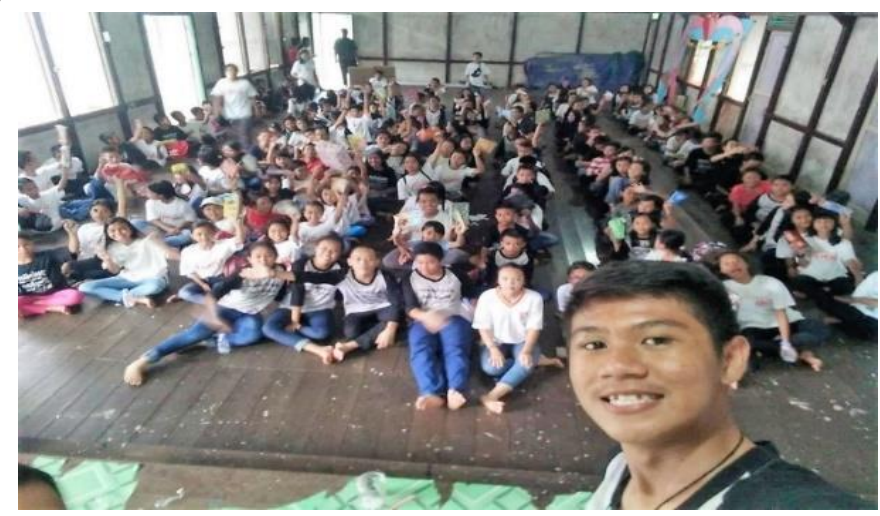

Figure 2. Waldi with the Ambawang Children's Forum (source: the researchers) 
Waldi is a Dayak and the President of the Ambawang Children's Forum, Kubu Raya Regency, West Kalimantan. By joining the Forum, Waldi earned many benefits that have changed his life for the better within this two years. Waldi's benefits are in line with Arendt's opinion that from his/her action and talk, a person can show who s/he is and reveal his/her social identity (Indah, 2016).

At the moment, the togetherness experienced by Waldi and his friends reflects homogenous togetherness because the most of the children in the Ambawang Children 's Forum are Dayak. However, this condition may be temporary because, in the future, the Forum might reach children from all ethnic groups in the Ambawang River area.

In contrast, Farhana Fitria who participated in the Children's Forum in urban areas has experienced activities with a more diversed ethnic groups. Fitria has had different benefits from the Forum.

"I know more about the outside world. I have more friends. I know about children's rights. Ifeel comfortable to know the outside world which actually leads to positive things because children at my age are curious about many things. And my parents also support my participation in the children's forum." (Fitria, personal communication, February 20, 2019, 17.36 WIB - Western Indonesian Time)

Fitria basically comes from a multi-ethnic family. Her father and mother have an inter-ethnic marriage between Madurese and Sambas Malay. By joining the Children's Forum, Fitria avoids negative things, and she can dedicate herself into positive activities.

Indah (2016) describes Arendt's opinion on the term 'ultimate' or the human ability to live together in diversity. A person cannot be a human with ultimate ability if s/he does not get support from other people who live their lives in labor and work which are inferior than action in which the human ability to act and speak in a diversed communities can be demonstrated. The understanding of this ultimate human is carried out by children in the West Kalimantan Children's Forum whose interaction and activities are emphasized on action without discrimination.

"I was taught to respect others and to stop making fun of others. Basically, we are taught not to discriminate others although the Forum consists of children from different ethnic groups. So, we have to intermingle with the others. So no discrimination." (Fitria, personal communication, February 20, 2019, 17.36 WIB--Western Indonesian Time)

Until now, the process of collective forgiveness has been limited only to continuous meetings so that the members of the West Kalimantan Children's Forum can be integrated into ultimate humans. In the ultimate domain, the ultimate ability can foster pluralism if there is a willingness to live in diversity. Farhana Fitria has experienced some differences by intermingling with other children. Fitria thinks that the Forum is indeed a place where there is no discrimination whatsoever. Waldi who started in the rather homogeneous Forum in Ambawang managed to experience a more heterogeneous conditions when he followed the Forum to a higher level: the Kuburaya Regency Children's Forum. In Kuburaya Children's Forum, the diversity is obvious; thus, the need to respect one another is getting higher.

Dialectics of Forgiveness of the West Kalimantan Young Generation

In general, the process of collective forgiveness is an alternative for each individual to have a better understanding about the inter-ethnic harmony that leads to collaboration regarding the two processes so that the dialectic process of forgiveness can take place. This process is related to Hegel's ideas about the dialectic concept which consists of three phases: 'thesis,' 'antithesis,' and 'synthesis.' Then, there is also the term 'aufgehoben' which unites the thesis and antithesis in the synthesis phase, so there are 3 meanings: (1)

Jurnal The Messenger, Vol. 12, No. 1, January 2020, pp. 1-13 
overriding; (2) caring for, storing, and not being eliminated; and (3) placing on a higher ground where the thesis and antithesis do not function as rivals (Suyahmo, 2007).

The application of Hegel's dialectics related to the process of forgiveness is interpreted further when individual forgiveness is expected (thesis), but it turns out that this does not occur completely, so the collective forgiveness emerges in various groups of inter-ethnic organizations (antithesis). Then the thesis and the antithesis are reconciled by a collaboration in which collective forgiveness promotes the emergence of individual forgiveness which creates inter-ethnic harmony in West Kalimantan (synthesis).

From another angle, community leaders gave their perspective as a response to the presence of the Children's Forum as a forum for children harmony in West Kalimantan, Subro, the cultural coordinator of the Madurese Family Association, gave his remarks that the activities in the Children's Forum can reduce the number of children who are exposed to stereotypes because the activities encourage the younger generation to accept differences, to be open-minded, and to interact based on nondiscrimination with other fellow members of the West Kalimantan Children's Forum.

"I think the forum is good, and it is needed in our area to break the primordialism barriers in the community. It is particularly needed for children to counter other children who have been exposed to stereotyping in their environment. I think it is good, and it is even better if the forum can continue beyond Junior High School students. This is to protect them from the danger of stereotyping which is easily spread by word of mouth. When the children are continuously exposed to this negative stereotyping, there is a possibility that the stereotyping will enter their minds and can be materialized into dangerous tangible forms which can grow stronger although it is just stereotyping." (Subro, personal communication, January 17, 2019, 17:56 WIB--Western Indonesian Time)

Another opinion regarding the presence of the Children's Forum came from Yohanes Bahari, a professor of Sociology and Conflict Resolution in the Faculty of Teacher Training and Education, Universitas Tanjungpura, West Kalimantan. Bahari believes that the benefits of the forum can be reflected as the means to reduce the tension of injustice because he thinks that the reconciliation process cannot be maximized as long as the injustice to members of the multiethnic societies is still visible in our everyday life.

"This forum is actually good as an effort to reduce the tension of injustice, but no matter how many forums like this are made, the efforts will not eradicate conflicts if injustice practices still occur. So, the forum is only a small portion of efforts to reduce conflicts. The root of the problem is actually injustice. When injustice practices still occur, no matter how much effort has been spent by independent organization, interethnic organization, interfaith organization, it will not be able to get rid of the potential for conflicts. Nevertheless, I think this kind of forum is good, at least for the purpose of reducing tension among the young generation." (Bahari, personal communication, January 24, 2019, 7:37 WIB--Western Indonesian Time)

The drawback of this Children's Forum is the fact that the forum has not been equipped with the adequate means to create conflict reconciliation. The current educational activities have not been directed specifically to goals, i.e. respecting differences and getting to know the ethnic group characteristics because, basically, every ethnic group has its own way of accepting the differences. Up to now, the forum's activities have been limited only to learn about children's rights and their obligations although what the children really need are special approaches and lessons on multiculturalism so that they can understand the dynamics of inter-ethnic groups in West 
Kalimantan. In line with this finding, Marta (2017) considers the imminent need of the means to create cross-fertilization between cultures which is feasible to be implemented in this situation in order to encourage the children to gain an understanding of their cultural identity.

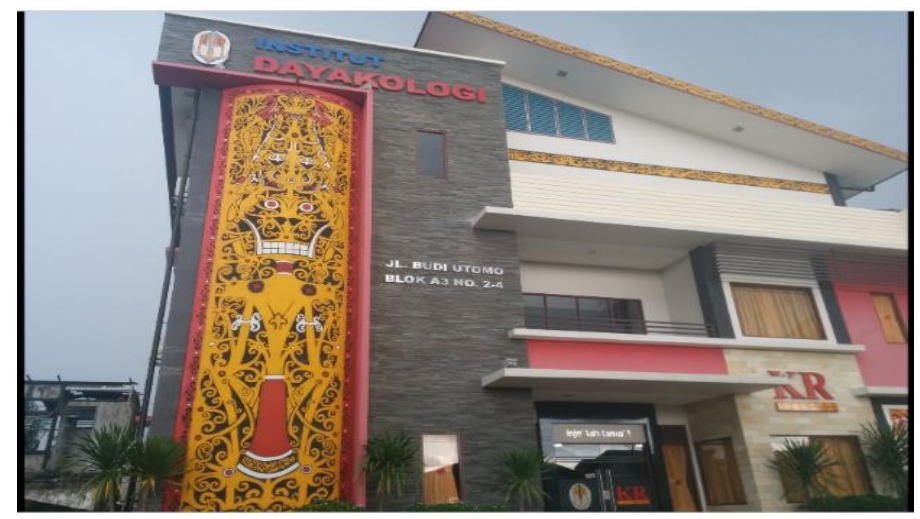

Figure 3. Institute of Dayaklogi Building (source: the researchers)

The West Kalimantan Children's Forum is not the only place that provides an 'oasis' of harmony for the local society. There is also the Institute of Dayaklogi (ID), which is an umbrella organization for overseeing diversity along with other institutions by forming the Peace and Transformation Alliance (ANPRI) which aims to have a forum for discussing the process of reconciliation, peace, and diversity. ANPRI is one example of a collective group consisting of individuals who want to openly discuss peace, one of which is the reconciliation of inter-ethnic conflicts. Efforts to reduce conflicts need to be done continuously through various social constructions. There has been harmonization which is realized through symbolic interactions across history (Sya \& Marta, 2019; Sya, Marta, \& Sadono, 2019).

" ... The Institute of Dayaklogi initiated the formation of the Peace and Transformation Alliance, formerly known as the Non-Government Organization for Peace and Transformation which was also abbreviated to ANPRI. It used to accommodate only the cross-ethnic NGOs, but in this era, the Peace and Transformation Alliance is not only for NGOs but also for all groups and even certain public figures who want to join the institute. Now we have around 50 members. And the host is still the Institute of Dayaklogi which also manages the administration. We also create peace groups. We publish a special column entitled 'Kerabat' which is a special column for peace in the Kalimantan Review (KR) magazine. Now the KR documents can be viewed at www.kalimantanreview.com." (Gunui, personal communication, January 12, 2019, 11.06 WIB--Western Indonesian Time)

At a larger level, there have been various discussions attended by representations of various ethnic groups, i.e. their community leaders, and the discussions have become a forum to encourage multiethnic communities to have a joint self-introspection (selfevaluation) session during the discussion.

"The progress at the community level is much better and very progressive, e.g. intergovernmental relations, the relations between Madurese and Dayak, the relations between Madurese with Malay, the relations between Madurese with Chinese, and the relations between Madurese with other tribes. Their responses are very positive. There is even this cross-ethnic forum which meets alternately every month in West Kalimantan. For examples, this month is in MABM, the next month is at the Madura Big Family Association, BAD, or MABT. So, they take turns in discussing current development." 
(Subro, personal communication, January 17, 2019, 14.56 WIB--Western Indonesian Time)

Pettigrove (2006) reviews Arendt's notion of collective forgiveness in which Arendt claims that giving forgiveness and relationships with each other are individual matters. This condition mainly occurs when the group's willingness to carry out collective forgiveness is not necessarily in line with the individual's willingness to forgive. In this case, based on Arendt's notion, the ability of organizations, e.g. the Children's Forum, the Dayaklogi Institute, the Alliance for Peace and Transformation, and other ethnic group organizations, cannot be the only guarantee for complete forgiveness which is done by individuals whose ethnic background may have involved in the conflicts. The conflict cannot be referred to as 'who' so that it becomes a separate responsibility; thus, in this case, the nation's next generation in the Children's Forum and children in West Kalimantan in general are encouraged to give collective forgiveness towards the rival ethnic group(s) with a limitation for children who do not experience the inter-ethnic conflicts in West Kalimantan.

With regard to the obstacles in the process, the government's support as public policy makers and executors is needed. This is in line with Pettigrove's brief explanation on political forgiveness (2006). By giving political forgiveness, policies can be adjusted to the conditions of the people in West Kalimantan which can encourage individuals to forgive the past events. Subro (2011) explains the example done by the Central Kalimantan regional government which carried out conflict resolutions which continued to the acts of tracing the assets of the victims of the inter-ethnic conflicts. This encourages local communities to experience regular recovery, including forgiveness in each individual.

\section{Conclusion}

The reconciliation process which has been done for around two decades makes the process of forgiveness in the community does not appear naturally. The encouragement from the collective group to give forgiveness emerges when there is a joint activity of planting shared values on harmony, peace, non-discrimination, and unity from various organizations which can lead to individual forgiveness. This whole process is called the 'dialectics of forgiveness.' The West Kalimantan Children's Forum, a forum for the younger generation, along with community organizations, e.g. the Association of Madurese Families, the Alliance for Peace and Transformation, the Institute of Dayaklogi, and various other organizations which are based on ethnic groups, work together, side by side, to maintain peace in West Kalimantan.

Conflict management in multicultural groups can be likened to group management whose members are multicultural; thus, they require equality that is applied to all members so that the shared group identity can be developed (Boroş, Meslec, Curşeu, \& Emons, 2009). Justice for the ethnic groups can be promoted by the participation of the West Kalimantan Regional Government which must play an active role in the reconciliation process, e.g. tracing the assets of the conflict victims and facilitating meetings between ethnic groups to foster equality and justice for the multiethnic communities.

Academically, this present study recommends communication studies as the basis for openness in all collective groups so that the discussion space can be widely opened and a peace commitment is established. Future research activities are also expected to oversee the reconciliation. Practically, collective groups can work together with local 
governments to continue the reconciliation process so that peace can be experienced by all ethnic groups in West Kalimantan.

\section{Acknowledgements}

The highest appreciation and gratitudes are extended to all the institutions that have contributed to this present study, among others, the West Kalimantan Regional Government, the Pontianak City municipality, the Kubu Raya Regency Children's Forum, the Institute of Dayaklogi, the Association of Madurese Families, and, obviously, [Jurnal The Messenger] which provides a topic for the communication studies to deliver peace messages on an international scale.

\section{References}

Alqadrie, S. I. (1999). Konflik Etnis Ambon dan Sambas: Suatu Tinjauan Sosiologis. Jurnal Antropologi Indonesia, 36-57.

Arafat. (1998). Konflik Dayak-Madura di Kalimantan Barat. Universitas Gadjah Mada. Arendt, H. (1958). The Human Condition. Chicago: U of Chicago Press.

Arkanudin. (2006). Menelusuri Akar Konflik Antaretnik. Mediator: Jurnal Komunikasi, 7(2), 185-194. https://doi.org/10.29313/MEDIATOR.V7I2.1276

Boroş, S., Meslec, N., Curşeu, P. L., \& Emons, W. (2009). Struggles for cooperation: Conflict resolution strategies in multicultural groups. Journal of Managerial Psychology, 25(5), 539-554. https://doi.org/10.1108/02683941011048418

BPS. (2003). West Kalimantan Ethnicity.

Creswell, J. W. (1998). Qualitatif Inquiry and Research Design. California: Sage Publications, Inc.

Eri Petebang, E. (2000). Konflik Etnis di Sambas. Jakarta: Institut Arus Informasi.

Farady Marta, R. (n.d.). REFLEKSI HIBRIDITAS BUDAYA DALAM PANCASILA PADA REALITAS DAN MEDIA SEBAGAI IDENTITAS BANGSA. Jurnal Bricolage, 3(1).

Fernando, J., \& Marta, R. F. (2015). Resolusi Konflik melalui Model Pengampunan Vita Activa Arendt dalam Komunikasi Generasi Muda Kalimantan Barat. Jurnal ASPIKOM, 4(2), 113-128.

Fernando, J., Sya, M., \& Marta, R. F. (2019). Amalgamation as a Strengthening Ethic. MIMBAR: Jurnal Sosial Dan Pembangunan, 35(2), 334-341. https://doi.org/10.29313/mimbar.v35i2.4863

Hidayat, Y. (2013). HUBUNGAN SOSIAL ANTARA ETNIS BANJAR DAN ETNIS MADURA DI KOTA BANJARMASIN. Jurnal Komunitas, 5(1), 87-92.

Indah, A. V. (2016). Jatidiri Manusia Berdasarkan Filsafat Tindakan Hannah Arendt Perspektif Filsafat Manusia: Relevansi Dengan Pelanggaran Ham Tahun 19651966 Di Indonesia. Jurnal Filsafat, 25(2), 277. https://doi.org/10.22146/jf.12686

Januarti, \& Wempi, J. A. (2019). MAKNA TENUN IKAT DAYAK SINTANG DITINJAU DARI TEORI SEMIOTIKA SOSIAL THEO VAN LEEUWEN. Bricolage : Jurnal Magister Ilmu Komunikasi, 5(1), 73-90.

Kohen, A. (2009). The personal and the political: forgiveness and reconciliation in restorative justice. Critical Review of International Social and Political Philosophy, 12(3), 399-423. https://doi.org/10.1080/13698230903127911

Man, N. I., Abdullah, A. P. D. Z., Tamam, E., \& Hasan, N. A. (2019). A Communications Strategy of the Malaysian Research Universities to add Value. Jurnal The Messenger, 11(1), 56. https://doi.org/10.26623/themessenger.v11i1.1211 
Marta, R. F. (2018). Perjuangan Multikulturalisme Perhimpunan Indonesia Tionghoa Dalam Perspektif Rekognisi Axel Honneth. Bricolage: Jurnal Magister Ilmu Komunikasi, 4(01), 23-31. https://doi.org/10.30813/bricolage.v4i01.1065

Mulyana, D. (2013). Metodologi Penelitian Kualitatif. Bandung: PT. Remaja Rosdakarya.

Paramita, S., \& Carissa, R. M. (2018). Inter-Ethnic Communication Barriers in Pontianak $\begin{array}{llll}\text { City. Jurnal } & \text { The }\end{array}$ https://doi.org/10.26623/themessenger.v10i1.550

Pettigrove, G. (2006). Hannah Arendt and Collective Forgiving. Journal of Social Philosophy, 37(4), 483-500. https://doi.org/10.1111/j.1467-9833.2006.00353.x

Safi, J. (2017). Konflik Komunal: Maluku 1999-2000. ISTORIA: Jurnal Pendidikan Dan Ilmu Sejarah, 13(1). https://doi.org/10.21831/istoria.v13i1.17615

Sahertian, C. (2016). Konstruksi Harmoni Internal Melalui Strategi Komunikasi Organisasi. Jurnal Nomosleca.

Subro. (2011). Suara Kami Buat Perdamaian. Pontianak: Cordaid-Caireu-YSDK-STAIN Pontianak Press.

Sumarni, E., Bahari, Y., \& Sulistyarini. (2016). Interaksi Sosial Kerja sama Masyarakat Multietnis (Dayak, Madura, Melayu) di Desa Kenaman Kecamatan Sekayam. Jurnal Pendidikan Dan Pembelajaran, 1-15.

Suyahmo. (2007). Filsafat Dialektika Hegel: Relevansinya dengan Pembukaan UndangUndang Dasar 1945. Humaniora, 19(2), 143-150.

Sya, M., \& Marta, R. F. (2019). Alignment Frame Construction by Three Online Newspapers on the Slogan of Bangka Belitung Islands. Jurnal Studi Komunikasi, 3(November), 332-354. https://doi.org/10.25139/jsk.3i3.1701

Sya, M., Marta, R. F., \& Sadono, T. P. (2019). TINJAUAN HISTORIS SIMBOL HARMONISASI ANTARA ETNIS TIONGHOA DAN MELAYU DI BANGKA BELITUNG. Jurnal Sejarah Citra Lekha, 4(2), 153-168.

Wirawan, W. (2009). Konflik dan manajemen konflik: Teori, aplikasi, dan penelitian. Jakarta: PT Bumi Aksara.

Wiwaha, D. T. J., \& Rosyid, U. N. (2017). Komunikasi Bisnis pada Etnis Tionghoa Studi Kasus Di Warung Kopi Asiang, Kota Pontianak,. Bricolage : Jurnal Magister Ilmu Komunikasi, 3(2), 118-155.

Yin, R. K. (2002). Studi Kasus: Desain \& Metode. Jakarta: PT. Raja Grafindo Persada.

Yohana, N., \& Yozani, R. E. (2017). Akomodasi Komunikasi Antarbudaya Imigran Ilegal Asal Afganistan Dengan Masyarakat Kota Pekanbaru. Jurnal Komunikasi, 11(2), 95. https://doi.org/10.21107/ilkom.v11i2.3324 